\title{
A fast and highly sensitive blood culture PCR method for clinical detection of Salmonella enterica serovar Typhi
}

\author{
Liqing Zhou* and Andrew J Pollard
}

\begin{abstract}
Background: Salmonella Typhi causes an estimated 21 million new cases of typhoid fever and 216,000 deaths every year. Blood culture is currently the gold standard for diagnosis of typhoid fever, but it is time-consuming and takes several days for isolation and identification of causative organisms. It is then too late to initiate proper antibiotic therapy. Serological tests have very low sensitivity and specificity, and no practical value in endemic areas. As early diagnosis of the disease and prompt treatment are essential for optimal management, especially in children, a rapid sensitive detection method for typhoid fever is urgently needed. Although PCR is sensitive and rapid, initial research indicated similar sensitivity to blood culture and lower specificity. We developed a fast and highly sensitive blood culture PCR method for detection of Salmonella Typhi, allowing same-day initiation of treatment after accurate diagnosis of typhoid.
\end{abstract}

Methods: An ox bile tryptone soy broth was optimized for blood culture, which allows the complete lysis of blood cells to release intracellular bacteria without inhibiting the growth of Salmonella Typhi. Using the optimised broth Salmonella Typhi bacteria in artificial blood samples were enriched in blood culture and then detected by a PCR targeting the flic- $d$ gene of Salmonella Typhi.

Results: Tests demonstrated that $2.4 \%$ ox bile in blood culture not only lyzes blood cells completely within 1.5 hours so that the intracellular bacteria could be released, but also has no inhibiting effect on the growth of Salmonella Typhi.

Three hour enrichment of Salmonella Typhi in tryptone soya broth containing $2.4 \%$ ox bile could increase the bacterial number from 0.75 CFU per millilitre of blood which is similar to clinical typhoid samples to the level which regular PCR can detect. The whole blood culture PCR assay takes less than 8 hours to complete rather than several days for conventional blood culture.

Conclusions: This novel blood culture PCR method is superior in speed and sensitivity to both conventional blood culture and PCR assays. Its use in clinical diagnosis may allow early detection of the causative organism and facilitate initiation of prompt treatment among patients with typhoid fever.

\section{Introduction}

Salmonella enterica serovar Typhi, the human-specific, causative agent of typhoid fever, causes an estimated 21 million new cases and 216,000 deaths every year [1]. It is generally thought that Salmonella enterica serovar Typhi, an enterically acquired invasive pathogen, penetrates the ileal epithelium and is transported via underlying macrophages to spleen, liver, and other target tissues during

* Correspondence: Liqing.Zhou@paediatrics.ox.ac.uk

1 Oxford Vaccine Centre, University of Oxford, Oxford, UK

Full list of author information is available at the end of the article the normal disease course. Natural clearance of the disease is thought to entail development of specific humoral and cellular immune responses. However, the precise mechanisms of Salmonella serovar Typhi virulence and immune protection are not well understood, mainly due to the absence of a suitable animal model. We have been developing a human typhoid challenge model which could increase understanding of the pathogenesis of typhoid fever, the immunobiology of the disease and the correlates of protection, and provide a model for evaluation of new vaccines. In the case of Salmonella serovar 
Typhi, there is an urgent need for new improved vaccines, as those currently available all have limitations. In the planned clinical typhoid challenge study the volunteers will receive oral inoculation with wild-type Salmonella serovar Typhi, followed by monitoring for 14 days to detect the presence and load of Salmonella serovar Typhi in blood, which requires a robust, rapid and sensitive method of detection of Salmonella serovar Typhi.

Currently there is lack of reliable, rapid and sensitive methods for the clinical detection Salmonella serovar Typhi. In the regions where enteric fever is common, clinical diagnosis of typhoid fever is inadequate, as the symptoms it causes are non-specific and overlap with those of other febrile illness, such as vector-borne malaria, dengue fever and rickettsioses as well as environmentally transmitted leptospirosis and melioidosis [2,3]. Serological tests, predominantly the Widal test, are available but have very low sensitivity and specificity, and no practical value in endemic areas despite their continued use [4]. Isolation of the causative organism remains the most effective diagnostic method in suspected typhoid fever and blood has been the main sample for culture for Salmonella serovar Typhi since 1900 [5,6]. The sensitivity of blood culture is highest in the first week of the illness and reduces with advancing illness [7]. However, blood culture is time-consuming and takes at least 2 to 5 days until the identification of the organism. Blood culture can identify 45 to $70 \%$ of patients with typhoid fever, depending on the amount of blood sampled, the bacteraemic level of Salmonella serovar Typhi, the type of culture medium used, and the length of incubation period [8,9]. Several factors may contribute to failure to isolate the organism from blood, including inadequate laboratory media, intrinsic bactericidal activity of blood, the volume of blood taken for culture, the presence of antibiotics and the time of blood collection. The intracellular nature of Salmonella serovar Typhi also slows its growth in blood culture media. One study found that more than $50 \%$ of bacterial cells were present intracellularly in the blood from patients with typhoid fever [8]. In the first review of blood culture in typhoid fever in 1907 Coleman recommended the use of ox bile broth [10]. Its superior qualities were attributed to the inhibition of bactericidal activity of blood and its ability to release intracellular bacteria [11].

Given the problems associated with the diagnosis of typhoid fever by blood culture and serological methods, PCR methods were recently exploited. Several studies have been reported since the first evaluation of PCR as a diagnostic tool for typhoid fever in 1993 when Song et al. successfully amplified the flagellin gene $(f l i C-d)$ of Salmonella serovar Typhi in all cases of culture proven typhoid fever and from none of the healthy controls [12-18]. These studies reported excellent sensitivity and specificity when compared to positive (blood culture proven) and healthy controls. The clinical utility of these PCR tests was inadequately evaluated though some studies claimed that as few as 10 bacteria per millilitre of blood could be detected. The number of Salmonella bacteria circulating in the blood of a patient with Salmonella bacteremia is small. One study found 0.5-22 bacteria per millilitre of blood in 15 patients with typhoid fever [19], and another showed a median of 0.3 (IQR, 0.1-10) bacteria per millilitre of blood from 81 patients with typhoid fever [8]. The very low ratio of bacterial to human DNA means that the PCR template in clinical preparations is dominated by mammalian DNA and could cause false-positive PCR signals due to the non-specific binding of primers and falsenegative results due to reduced sensitivity. In practice, the large excess of human DNA does indeed cause problems for PCR-based pathogen detection in blood, particularly in samples with low bacterial numbers [20,21]. Furthermore, small volumes of blood are often used for DNA extraction or as template in the PCR, which will significantly lower the sensitivity of these tests.

In the present study, we describe a fast and highly sensitive blood culture PCR method for detection of Salmonella serovar Typhi. The method uses the optimised ox bile-containing medium in blood culture for enrichment of bacteria, combined with a PCR assay, to reduce turnaround time for diagnosis and increase diagnostic sensitivity.

\section{Materials and methods Strains and culture}

Wild-type Salmonella serovar Typhi Quailes strain was obtained from the University of Maryland through Centres for Disease Control and Prevention, Atlanta, USA. The strain was originally isolated from a carrier in 1958, and was previously used as a challenge strain over 20 years (in the 1960s and 1970s) during which almost 2000 volunteers ingested the strain as participants in vaccine efficacy and pathogenesis studies. The strain was last stored in 1988 and was maintained frozen until shipping to Oxford in 2008. In this study the strain was sub-cultured in tryptone soya broth (TSB) or on tryptone soya agar (TSA) (Oxoid, Basingstoke, UK) as needed.

\section{Preparation of Salmonella serovar Typhi Quailes strain inocula}

Salmonella serovar Typhi Quailes strain was cultured on TSA plate for 16 hours at $37^{\circ} \mathrm{C}$, and collected in TSB medium. The culture was first adjusted to an optical density at $600 \mathrm{~nm}$ of 0.25 and then prepared for serial 10 -fold dilutions in TSB. The number of Salmonella bacteria per millilitre was determined by plating each dilution onto TSA plates. Colonies were counted after incubation of the plates overnight at $37^{\circ} \mathrm{C}$. 


\section{Growth of Salmonella serovar Typhi Quailes strain in TSB- bile medium}

About 2-6 colony-forming-unit (CFU) of Salmonella serovar Typhi Quailes strain in $0.1 \mathrm{ml}$ TSB was inoculated into $20 \mathrm{ml}$ TSB each containing $0,1.2,1.6,2.0,2.4,4.0$ and $10.0 \%(\mathrm{w} / \mathrm{v})$ of ox bile (Oxgall, BD Biosciences, Oxford, UK). The culture was shaken at 200 revolutions per minute (RPM) at $37^{\circ} \mathrm{C}$ in an incubator for 5 hours, and then centrifuged at $6,000 \times \mathrm{g}$ for $20 \mathrm{~min}$. The pellet was re-suspended in $0.5 \mathrm{ml}$ TSB and plated onto TSA plates. The plates were incubated overnight at $37^{\circ} \mathrm{C}$ and colonies were counted.

\section{Lysis of blood cells in TSB-bile medium}

Blood was removed from healthy individuals with a sterile syringe and immediately pipetted into tubes containing heparin. $1 \mathrm{ml}$ of blood was mixed with $4 \mathrm{ml}$ of TSB each containing $0,1.5,2.0,2.5,3.0$ and $5.0 \%(\mathrm{w} / \mathrm{v})$ of ox bile, giving final concentrations $0,1.2,1.6,2.0,2.4$ and $4.0 \%(\mathrm{w} / \mathrm{v})$ of ox bile and $20 \%(\mathrm{v} / \mathrm{v})$ of blood. The mixture was gently shaken for up to 5 hours at room temperature. $10 \mu \mathrm{l}$ samples were taken periodically and mixed with 200 $\mu \mathrm{l}$ phosphate buffered saline (PBS). The lysis of blood cells was examined by microscopy.

\section{TSB-bile blood culture of Salmonella serovar Typhi Quailes} strain

For blood culture of Salmonella serovar Typhi Quailes strain, $4 \mathrm{ml}$ blood was spiked with 2-6 CFU of Salmonella serovar Typhi, and then mixed with $16 \mathrm{ml}$ TSB containing $3.0 \%(\mathrm{w} / \mathrm{v})$ ox bile in a $50 \mathrm{ml}$ tube, giving a final concentration of ox bile at $2.4 \%(\mathrm{w} / \mathrm{v})$ and blood at $20 \%(\mathrm{v} / \mathrm{v})$. The culture was shaken at $200 \mathrm{RPM}$ at $37^{\circ} \mathrm{C}$ in an incubator for up to 5 hours. Two tubes were removed from the incubator every hour and the cells were collected by centrifugation at $6,000 \times \mathrm{g}$ for $20 \mathrm{~min}$. The supernatant was discarded and the pellet was re-suspended in $0.5 \mathrm{ml} \mathrm{TSB}$. One tube was plated onto TSA plates for determination of the number of CFU in each sample and another tube was used for DNA extraction.

\section{DNA extraction}

DNA was isolated from the culture using UltraClean ${ }^{\mathrm{m}}$ BloodSpin $^{\text {Tw }}$ Kit (MO BIO Laboratories, CA, USA) according to the manufacturer's instruction, except that the DNA was eluted with $100 \mu$ l Buffer 5 and incubated at $65^{\circ} \mathrm{C}$ for $5 \mathrm{~min}$ before centrifugation. The aliquots of DNA preparation were separated by electrophoresis on $1 \%$ agarose gels, stained with ethidium bromide, and photographed by a UV transilluminator. The quantity and quality of the DNA preparations were compared.

\section{PCR Primers of Salmonella serovar Typhi Quailes strain} The PCR primers for Salmonella serovar Typhi Quailes strain were designed according to the fliC-d gene sequence of Salmonella serovar Typhi (Accession number L21912): H-for (ACTCAGGCTTCCCGTAACGC) and Hd-rev (GGCTAGTATTGTCCTTATCGG) [22], and synthesized by Sigma Genosys (Sigma-Aldrich, Dorset, England).

\section{PCR protocol}

The PCR reaction was carried out in a $50 \mu$ l volume, comprising $0.5 \mathrm{U}$ of Taq DNA polymerase (Qiagen, Crawley, UK), $1 \times$ Qiagen PCR buffer, $1.5 \mathrm{mM}$ magnesium chloride, $200 \mu \mathrm{M}$ concentrations of each deoxynucleoside triphosphate, $0.5 \mu \mathrm{M}$ concentrations of the primers $\mathrm{H}$-for and Hd-rev, and $10 \mu \mathrm{l}$ of DNA template. The following amplification steps were used: 1 cycle of $95^{\circ} \mathrm{C}$ for $5 \mathrm{~min}$; 35 cycles of $93^{\circ} \mathrm{C}$ for $30 \mathrm{sec}, 55^{\circ} \mathrm{C}$ for $30 \mathrm{sec}$, and $72^{\circ} \mathrm{C}$ for $40 \mathrm{sec}$; and $1 \mathrm{cycle}$ of $72^{\circ} \mathrm{C}$ for $5 \mathrm{~min}$. The PCR amplification product was separated by electrophoresis on a $1 \%$ agarose gel, stained with ethidium bromide, and photographed by a UV transilluminator.

\section{Results}

Effect of ox bile on the growth of Salmonella serovar Typhi Quailes strain

The growth of Salmonella serovar Typhi Quailes strain in $20 \mathrm{ml}$ TSB containing different concentrations of ox bile inoculated with four CFU is shown in Figure 1. There was no difference in the growth of Salmonella serovar Typhi Quailes strain in TSB with bile concentrations between 0 and $2.0 \%$. At a bile concentration of $2.4 \%$, the growth of Salmonella serovar Typhi Quailes strain became slower than those at the lower bile concentrations. However, $4.0 \%$ bile reduced the growth of Salmonella serovar Typhi Quailes strain by more than $50 \%$, and eventually Salmonella serovar Typhi Quailes strain stopped growing when the bile concentration reached $10.0 \%$.

\section{Effect of ox bile on blood cells}

Bile rapidly and completely lyzed blood cells (see Table 1). No lysis of blood cells was found in TSB, and only partial lysis at a bile concentration of $1.2 \%$, even after incubation for up to 5 hours. However, the blood cells were completely lyzed within 3 hours at a bile concentration of $1.6 \%$ and above. The higher the bile concentration, the faster the lysis of blood cells.

\section{Growth and PCR detection of Salmonella serovar Typhi Quailes strain in TSB-bile blood culture system}

Based on the effect of bile on the growth of Salmonella serovar Typhi Quailes strain and the observation that bile did lyze blood cells, a TSB-bile blood culture system containing 2.4\% ox bile and 20\% blood was selected for Salmonella serovar Typhi Quailes strain blood culture. Table 2 shows the effect on CFU counts and PCR detection of Salmonella serovar Typhi Quailes strain using the TSBbile blood culture system. The culture started from 3 


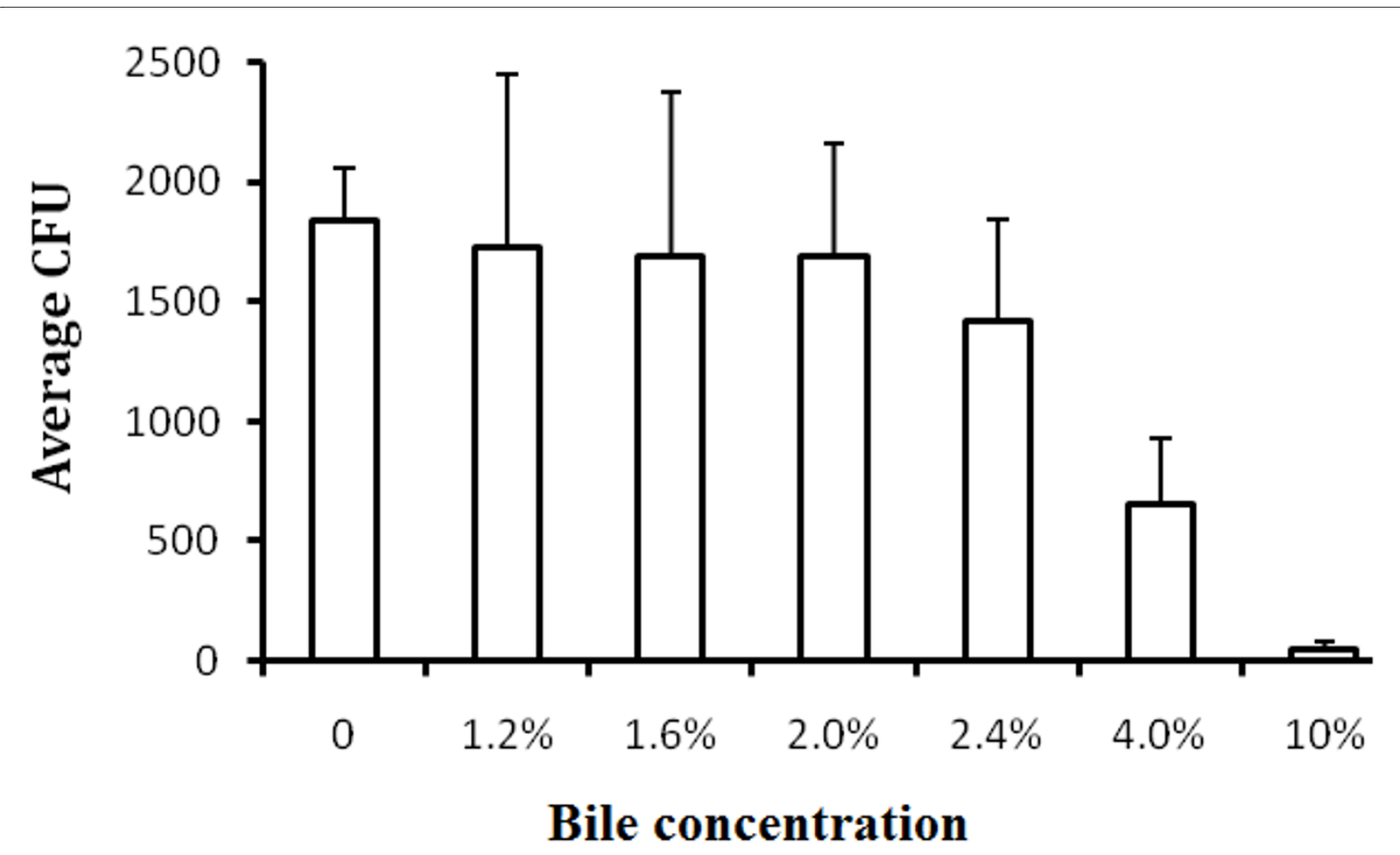

Figure 1 The growth of Salmonella serovar Typhi Quailes strain in TSB containing different concentrations of ox bile. Four bacteria were incubated in $20 \mathrm{ml} \mathrm{TSB}$ containing different concentrations of bile at $37^{\circ} \mathrm{C}$ for 5 hours. The CFU was the mean of three independent cultures.

CFU, and grew about 10 generations within 5 hours of incubation in this culture system. In the first hour the bacteria did not multiply, but the growth gradually picked up from the second hour. The number of CFU increased from 3 to 105 within 3 hours and rose more than thousand times during 5 hours of incubation. When the DNA, prepared periodically from the cultures, was used as PCR template, the amplicons of fliC-d gene of Salmonella serovar Typhi Quailes strain were seen, as shown in Figure 2. Three independent experiments found that the flic-d gene of Salmonella serovar Typhi in the DNA preparations made from the cultures after 3 to 5 hours of incubation was detected by PCR, but not in those made from the cultures incubated for less than 3 hours (see

Table 1: Effect of ox bile on blood cells.

Bile concentration (\%)

\begin{tabular}{|c|c|c|c|c|c|c|}
\hline $\begin{array}{l}\text { Incubation } \\
\text { time (hour) }\end{array}$ & 0 & 1.2 & 1.6 & 2.0 & 2.4 & 4.0 \\
\hline 1 & & & & & & Complete \\
\hline 1.5 & & & & & Complete & \\
\hline 2 & & & & Complete & & \\
\hline 3 & & & Complete & & & \\
\hline 5 & No & Partial & & & & \\
\hline
\end{tabular}




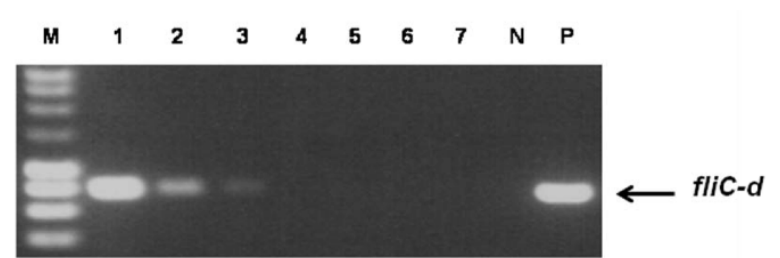

Figure 2 Salmonella serovar Typhi fliC- $d$ amplicons (763 bp) on a $1 \%$ agarose gel. Lanes: $M$, DNA marker; 1,5 hour culture; 2,4 hour culture; 3, 3 hour culture, 4, 2 hour culture; 5, 1 hour culture; 6, 0 hour culture; 7, No DNA template negative control; N, 5 hour blood culture control without bacteria; $\mathrm{P}$, Salmonella serovar Typhi DNA positive control.

Table 2). Taking account of the fact that $10 \mu \mathrm{l}$ of the $100 \mu \mathrm{l}$ DNA preparations made from the cultures was used in each PCR reaction, and the $f l i C-d$ amplicons were only seen in the cultures with more than 105 CFU of Salmonella serovar Typhi shown in Table 2, the limit of detection for this assay was about 10 CFU per PCR reaction. This study used a $4 \mathrm{ml}$ blood sample spiked with 3 CFU of Salmonella serovar Typhi Quailes strain for the culture, and therefore the sensitivity of this blood culture-PCR method was equivalent to $0.75 \mathrm{CFU}$ per millilitre of blood. At least three hours of incubation were needed for the bacteria to be enriched to a detectable level with a regular PCR.

\section{Discussion}

Blood culture is currently the gold standard for diagnosis of typhoid fever, but it takes several days for the isolation

\section{Table 2: The growth and PCR detection of Salmonella} serovar Typhi in TSB-bile blood culture *

\begin{tabular}{ccc}
$\begin{array}{l}\text { Incubation } \\
\text { time (hour) }\end{array}$ & CFUa & filC-d ampliconsb \\
\hline 0 & 3 & --- \\
\hline 1 & 4 & --- \\
\hline 2 & 17 & --- \\
\hline 3 & 105 & +++ \\
\hline 4 & 209 & +++ \\
\hline 5 & 4461 & +++ \\
\hline
\end{tabular}

*Three bacteria of Salmonella serovar Typhi were incubated in the TSB-bile blood culture containing $2.4 \%$ ox bile and $20 \%$ blood. ${ }^{a}$ The mean of three independent experiments; ${ }^{b}$ Salmonella serovar Typhi fliC- $d$ amplicons resulting from PCR using the DNA templates prepared from three independent cultures. and identification of causative organisms. As early diagnosis of the disease and prompt treatment are essential for optimal management, especially in children, a rapid sensitive detection method for typhoid fever is urgently needed. PCR is sensitive and rapid, and could possibly replace blood culture as the new "gold standard". However, initial research indicated similar sensitivity to blood culture and lower specificity [23].

Given the problems associated with conventional methods for diagnosis of typhoid fever, the present study was carried out in an attempt to develop a rapid, reliable, specific, and sensitive method for detection of Salmonella serovar Typhi. Artificially spiked blood samples were used throughout the study to mimic clinical specimens in the development and evaluation of a blood culture PCR method for detection of Salmonella serovar Typhi.

Early studies found that the number of Salmonella bacteria circulating in the blood of patients with Salmonella bacteremia is small, e.g. 0.5-22 bacteria per millilitre of blood found in 15 patients with typhoid fever [19], fewer than 2 bacteria per millilitre of blood found in $90 \%$ of 80 positive blood cultures from patients with Salmonella bacteremia [11], and a median of 0.3 (IQR, 0.1-10) bacteria per millilitre of blood in further 81 patients with typhoid fever [8]. Therefore, it is very important to use small bacterial inocula when developing and evaluating a system for detection of Salmonella serovar Typhi in clinical specimens. In the present study, blood samples were spiked with Salmonella serovar Typhi Quailes strain at a ratio of $1 \pm 0.5 \mathrm{CFU}$ per millilitre of blood, which closely mimics clinical specimens taken from patients with typhoid fever.

The initial evaluation study, in which 2-6 CFU of Salmonella serovar Typhi Quailes strain were mixed with 4 $\mathrm{ml}$ of blood and then cultured in TSB medium, found that the bacteria did not grow during 5 hours of incubation. The results remained the same when blood samples taken from different healthy donors were used. Moreover, when blood was artificially inoculated with a small number of Salmonella bacteria, followed by plating, fewer bacteria were recovered from the inoculated blood samples than the input (data not shown). This, consistent with other studies $[11,19,24,25]$, clearly demonstrates that human blood has bactericidal activity against Salmonella serovar Typhi. Furthermore, one study found that the defibrinated whole blood from patients with Salmonella bacteremia was bactericidal for small inocula of three of five Salmonella strains isolated from the patient's blood [24]. This suggests that the blood or serum of patients with Salmonella bacteremia is also frequently bactericidal against the Salmonella isolated from their blood. Therefore, a culture medium which inhibits the bactericidal activity of blood may be beneficial in the development of a blood culture-PCR assay system. 
Since bile was first used for blood culture of patients with Salmonella bacteremia in 1906 [26], bile containing media have repeatedly been found superior for isolation of enteric fever pathogens (Salmonella serovars, Typhi and Paratyphi) from whole blood [11]. Conradi attributed the effectiveness of bile as a culture medium to its effect in preventing coagulation of blood [26], and further demonstrated that bile decreases the bactericidal activity of serum [27]. Although Kaye et al. did not find that the anticoagulant effect was an important factor in the superiority of bile over TSB as a blood culture medium for Salmonella, they confirmed and expanded the observation that bile decreases the bactericidal activity of serum [11]. They found that bile inactivated the complement activity of blood, and also disrupted leukocytes in which Salmonella may be present. They argued that in patients with Salmonella bacteremia rapid release of Salmonella from leukocytes by bile might be a very important factor contributing to the advantage of bile as a culture medium. The intracellular presence of Salmonella serovar Typhi was demonstrated by the study [8] showing that the number of CFU of Salmonella serovar Typhi per milillitre sample increased by 3.3 fold and 1.9 fold respectively when bone marrow and blood cells were lyzed. Therefore, a blood culture medium could increase bacterial growth if it contains blood cell lyzing agents. Having examined further the effect of bile on the growth of Salmonella serovar Typhi, the present study confirmed the observation that bile does not have a growth-promoting effect on Salmonella [11]. In fact, Salmonella serovar Typhi Quailes strain did not survive in $10 \%$ bile in the absence of TSB (data not shown). Furthermore, the present study also demonstrated that bile, in absence of blood, inhibits the growth of Salmonella serovar Typhi Quailes strain at high concentrations of bile in TSB-bile medium. In order to determine the concentration of bile for use in a TSB-bile blood culture system, the lysis of blood cells by bile was studied. The results showed that the lysis of blood cells depends on the bile concentration and incubation time. At a concentration of $2.4 \%$, bile not only lyzes blood cells completely within 1.5 hours so that the intracellular bacteria could be released, but also has no inhibiting effect on the growth of Salmonella serovar Typhi Quailes strain. Therefore, 2.4\% bile seems an optimal concentration for use in the TSB-bile blood culture system.

It has been asserted that PCR is sensitive and rapid, and is a better alternative than conventional methods for pathogen detection. In the last decade, PCR has been widely researched for early diagnosis of typhoid fever. PCR as a diagnostic tool for detection of Salmonella serovar Typhi was first studied by Song et al. [12] who developed a nested PCR for amplification of the fliC-d gene of Salmonella serovar Typhi which could detect 5 bacteria/ $\mathrm{ml}$, compared to $10^{6}$ bacteria $/ \mathrm{ml}$ by regular PCR. Recently, Ali et al. [18] reported a nested multiplex PCR for detection of both Salmonella serovars, Typhi and Paratyphi, with a sensitivity of 10 bacteria $/ \mathrm{ml}$. However, initial research indicated that PCR has similar sensitivity to blood culture and lower specificity [23]. This, at least in part, can be attributed to the low number of Salmonella bacteria circulating in the blood of typhoid patients and the inadequate method of DNA preparation. In normal clinical samples, there is a median of $0.3 \mathrm{CFU}$ per millilitre of blood which is far below the sensitivity of PCR so far developed, and therefore, it is not surprising that PCR has not been used for diagnosis of typhoid fever. To overcome the difficulties caused by the low numbers of Salmonella bacteria present in typhoid patient blood samples, pre-enrichment of bacteria is necessary prior to PCR detection. A recent study demonstrated that the 5 hour broth culture enrichment improved PCR sensitivity by 10 times for spiked blood, and 100 times for spiked stool samples [28]. The present study has used the optimized TSB-bile blood culture system, in which 0.75 bacteria per $\mathrm{ml}$ of blood was used to mimic real clinical samples, and $4 \mathrm{ml}$ blood for the culture with $3 \mathrm{CFU}$ in total, for enrichment of bacteria prior to the PCR detection of Salmonella serovar Typhi. At the bacterial level used in present study, it was very difficult to detect the presence of Salmonella serovar Typhi by regular PCR without bacterial enrichment and/or removal of human DNA. However, three hour enrichment of Salmonella serovar Typhi in the TSB-bile medium could increase the number of CFUs to the level at which detection is possible using regular PCR. The sensitivity of this novel blood culture PCR method was equivalent to $0.75 \mathrm{CFU}$ per millilitre of blood which is comparable to the bacterial number present in clinical typhoid samples. Moreover, the turnaround time of the assay was less than 8 hours rather than several days for conventional blood culture. Therefore, this new TSB-bile blood culture PCR system is superior (speed and sensitivity) to conventional blood culture and PCR methods and could potentially make early detection of Salmonella serovar Typhi possible for prompt treatment of patients with typhoid fever.

\section{Competing interests}

AJP acts as chief and principal investigator for clinical trials conducted on behalf of Oxford University, sponsored by vaccine manufacturers (Novartis Vaccines, GlaxoSmithKline, Sanofi-Pasteur, Sanofi-Pasteur MSD, and Wyeth Vaccines), but does not receive any personal payment from them. Industry sourced honoraria for consultancy, lecturing or writing and travel expenses and grants for educational activities are paid directly to an educational/administrative fund held by the Department of Paediatrics, University of Oxford or an independent charity.

\section{Authors' contributions}

LZ and AJP conceived of the study and carried out its design. LZ performed the assays and drafted the manuscript. AJP edited the manuscript. All authors read and approved the final manuscript. 


\section{Acknowledgements}

This work was supported by the Oxford Partnership Comprehensive Biomedical Research Centre Programme with funding from the Department of Health's NIHR Biomedical Research Centres funding scheme. AJP is a Jenner Institute Investigator. Wild-type Salmonella serovar Typhi Quailes strain was provided by University of Maryland.

\section{Author Details}

Oxford Vaccine Centre, University of Oxford, Oxford, UK

Received: 20 January 2010 Accepted: 19 April 2010

Published: 19 April 2010

\section{References}

1. Crump JA, Luby SP, Mintz ED: The global burden of typhoid fever. Bull World Health Organ 2004, 82:346-353.

2. Petit PL, Wamola IA: Typhoid fever: a review of its impact and diagnostic problems. East Afr Med J 1994, 71:183-188

3. Stuart BM, Pullen RL: Typhoid fever: clinical analysis of three hundred and sixty cases. Arch Intern Med 1946, 78:629-661.

4. Levine MM, Grados O, Gilman RH, Woodward WE, Solis-Plaza R, Waldman W: Diagnostic value of the Widal test in areas endemic for typhoid fever. Am J Trop Med Hyg 1978, 27(4):795-800,

5. Parry CM, Hien TT, Dougan G, White NJ, Farrar JJ: Typhoid fever. N EnglJ Med 2002, 347(22):1770-1782.

6. Wain J, Hosoglu S: The laboratory diagnosis of enteric fever. J Infect Developing Countries 2008, 2(6):421-425.

7. Kundu R, Ganguly N, Ghosh TK, Yewale VN, Shah RC, Shah NK: IAP Task Force Report: diagnosis of enteric fever in children. Indian Pediatr 2006, 43(10):875-883.

8. Wain J, Pham VB, Ha V, Nguyen NM, To SD, Walsh AL, Parry CM, Hasserjian RP, HoHo VA, Tran TH, Farrar J, White NJ, Day NP: Quantitation of bacteria in bone marrow from patients with typhoid fever: relationship between counts and clinical features. J Clin Microbiol 2001, 39(4):1571-1576.

9. Wain J, To SD, Phan VB, Walsh AL, Ha V, Nguyen MD, Vo AH, Tran TH, Farrar J, White NJ, Parry CM, Day NP: Specimens and culture media for the laboratory diagnosis of typhoid fever. J Infect Developing Countries 2008, 2(6):469-474.

10. Coleman W, Buxton BH: The bacteriology of the blood in typhoid fever. Amer J Med Sci 1907, 133:896-903.

11. Kaye $\mathrm{D}$, Palmieri $\mathrm{M}$, Rocha $\mathrm{H}$ : Effect of bile on the action of blood against Salmonella. J Bacteriol 1966, 91(3):945-952.

12. Song $\mathrm{H}$, Cho H, Park MY, Na DS, Moon HB, Pai CH: Detection of Salmonella typhi in the blood of patients with typhoid fever by polymerase chain reaction. J Clin Microbiol 1993, 31:1439-1443.

13. Haque A, Ahmed N, Peerzada A, Raza A, Bashir S, Abbas G: Utility of PCR in diagnosis of problematic cases of typhoid. Jpn J Infect Dis 2001, 54:237-239.

14. Kumar A, Arora V, Bashamboo A, Ali S: Detection of Salmonella typhi by polymerase chain reaction: implications in diagnosis of typhoid fever. Infect Genet Evol 2002, 2:107-110.

15. Massi MN, Shirakawa T, Gotoh A, Bishnu A, Hatta M, Kawabata M: Rapid diagnosis of typhoid fever by PCR assay using one pair of primers from flagellin gene of Salmonella typhi. J Infect Chemother 2003, 9:233-237.

16. Prakash P, Mishra OP, Singh AK, Gulati AK, Nath G: Evaluation of nested PCR in diagnosis of typhoid fever. J Clin Microbiol 2005, 43:431-432.

17. Hatta M, Smits HL: Detection of Salmonella typhi by nested polymerase chain reaction in blood, urine, and stool samples. Am J Trop Med Hyg 2007, 76(1):139-143.

18. Ali A, Haque A, Haque A, Sarwar Y, Mohsin M, Bashir S, Tariq A: Multiplex PCR for differential diagnosis of emerging typhoidal pathogens directly from blood samples. Epidemiol Infect 2009, 137:102-107.

19. Watson KC: Isolation of Salmonella typhi from the blood stream. J Lab Clin Med 1955, 46:128-134

20. Horz HP, Scheer S, Huenger F, Vianna ME, Conrads G: Selective isolation of bacterial DNA from human clinical specimens. J Microbiol Methods 2008, 72(1):98-102.

21. Handschur M, Karlic H, Hertel C, Pfeilstöcker M, Haslberger AG: Preanalytic removal of human DNA eliminates false signals in general 16S rDNA
PCR monitoring of bacterial pathogens in blood. Comp Immunol Microbiol Infect Dis 2009, 32(3):207-219.

22. Levy H, Diallo S, Tennant SM, Livio S, Sow SO, Tapia M, Fields PI, Mikoleit M, Tamboura B, Kotloff KL, Lagos R, Nataro JP, Galen JE, Levine MM: PCR method to identify Salmonella enterica serovars Typhi, Paratyphi A, and Paratyphi $B$ among Salmonella Isolates from the blood of patients with clinical enteric fever. J Clin Microbio/ 2008, 46(5):1861-1866.

23. Bhutta ZA: Current concepts in the diagnosis and treatment of typhoid fever. BMJ 2006, 333(7558):78-82

24. Khairat $\mathrm{O}$ : The bactericidal power of theblood for the infecting organism in bacteriaemia. J Pathol Bacteriol 1946, 58:359-365.

25. Mackie TJ, Finkelstein MH: Natural bactericidal antibodies: observationson the bactericidal mechanism of normalserum. J Hyg 1931, 31:35-55.

26. Conradi H: Ein Verfahren zum Nachweis der Typhuserreger im Blut. Deut Med Wochschr 1906, 32:58-61.

27. Conradi H: Ueber das Verhalten der imBlute der Typhuskranken nachweisbaren Typhusbazillen gegenuber der bakterizidenWirkung des Blutes. Muench Med Wochschr 1906, 53:1361

28. Teh CS, Chua KH, Puthucheary SD, Thong KL: Further evaluation of a multiplex PCR for differentiation of Salmonella paratyphi A from other salmonellae. Jpn J Infect Dis 2008, 61(4):313-314.

doi: 10.1186/1476-0711-9-14

Cite this article as: Zhou and Pollard, A fast and highly sensitive blood culture PCR method for clinical detection of Salmonella enterica serovar Typhi Annals of Clinical Microbiology and Antimicrobials 2010, 9:14

\section{Submit your next manuscript to BioMed Central and take full advantage of:}

- Convenient online submission

- Thorough peer review

- No space constraints or color figure charges

- Immediate publication on acceptance

- Inclusion in PubMed, CAS, Scopus and Google Scholar

- Research which is freely available for redistribution
C) BioMed Central 